\title{
TOWARDS IMPROVING THE APPLICABILITY OF THE RUSLE MODEL AT MOUNTAINOUS MEDITERRANEAN CATCHMENTS
}

\section{EFTHIMIOU N.* KARAVITIS C.}

Received: 23/02/2016

Accepted: $27 / 07 / 2016$

Available online: $28 / 07 / 2016$

\author{
Agricultural University of Athens \\ Department of Natural Resources Management and Engineering \\ Faculty of Water Resources Management, lera Odos 75, Athens, Greece
}

\section{ABSTRACT}

In here we present a modified version of the RUSLE model, which can perform better than the original version at mountainous, Mediterranean catchments. A weighing coefficient is assigned at each factor in the model resulting into a reduction in the model residuals (difference between modeled and observed sediment yield). Observations are based on sediment discharge measurements conducted by the Greek Public Power Corporation (PPC). The study area includes the catchments of Venetikos, Kalamas, Arachthos and Acheloos Rivers, which are very important aquatic systems of northwestern Greece. The cross-evaluation between the originally simulated (no coefficients) and observed sediment yields attributed an initial error term value of $40213.06 \mathrm{t} \mathrm{ha}^{-1}$. Subsequently, the model was modified (weighing coefficients were assigned regarding the PPC measurements) and the same procedure was followed, reducing the error term value to $25937.07 \mathrm{t} \mathrm{ha}^{-1}$. The ambiguous reliability of the PPC measurements led to their replacement by simulations using the sediment discharge rating curves methodology. The modified RUSLE model is based on different weighing coefficients assigned regarding the rating curves estimations. Results show that the error term was moreover reduced to $5834.78 \mathrm{t} \mathrm{ha}^{-1}$. The final equation was implemented to each subcatchment both at an annually and inter-annually scale in order to validate the model's reliability. Overall, the results were satisfactory.

Keywords: Soil Erosion; RUSLE; Venetikos; Kalamas; Acheloos; Arachthos

\section{Introduction}

According to the American Soil Science Society (2001), soil erosion is defined as "the wearing away of the land surface by physical forces such as rainfall, flowing water, wind, ice, temperature change, gravity or other natural or anthropogenic agents that abrade, detach and remove soil or geological material from one point on the earth's surface to be deposited elsewhere". Soil erosion constitutes a major environmental problem affecting the natural environment (land and water quality degradation, coastline alteration, river bank excavation increased flood risk etc), technical structures (dams, hydroelectric projects, bridges) and human activities (agriculture). The need to accurately assess and predict this phenomenon both temporally and spatially led to the development of different tools (e.g. erosion models such as USLE (Wischmeier and Smith, 1978), RUSLE (Renard et al., 1991; 1994; 1996), EPM (Gavrilovic, 1962), CREAMS (Knisel, 1980), WEPP (Nearing et al., 1989) etc.) and methodological approaches, e.g. frameworks based on biological-physical and socio-economic indicators (climate, water availability, drought, land use, agricultural practices, population criteria (density, economic status, age), fires, tourism, management policies) (Salvati et al., 2014). 
The empirical RUSLE model, despite its limitations (e.g. questionable performance on catchment scale where non uniform climatic, topographic and soil cover conditions occur etc.), is widely accepted and applied throughout the world (Bosco et al., 2009; Sigalos et al., 2010; Eftthimiou et al., 2014). The model estimates soil erosion as a linear product of six factors (precipitation, soil properties, topography, land cover, erosion control practices). Yet, since no weighing coefficient was originally assigned to its factors, it is implied that they all have the same effect on the erosion phenomenon. This assumption raises doubts concerning their role on the erosion processes (e.g. precipitation (and subsequently surface runoff) is the driving force of the phenomenon's manifestation, having a decisive role on its evolution, a fact that should be reflected by the model's mathematical equation).

This study aims to modify the Revised Universal Soil Loss Equation (RUSLE) to improve its applicability and skill at mountainous, Mediterranean catchments. Each of the model's individual factors was assigned with a proper weighing coefficient, taking under consideration, initially measured (by the Greek Public Power Corporation; PPC) and subsequently simulated (using sediment discharge rating curves) "observed" sediment yield values, in order to minimize the model error.

The RUSLE model was chosen considering a number of criteria including scientific validity (established methodology), low data requirements, computational speed, ease of use, low implementation cost, spatial implementation and graphical output data type (GIS) capability, other characteristics according to the methodological approach of Blinkov and Kostadinov (2010) (fulfilling various tasks (assessment of average pattern of erosion risk, identification of high risk areas, identification of hot spots, effects of conservation measures), application scale (field, watershed), solving various erosion types (sheet, rill erosion)), in accordance to the Greek input data regime (limited availability, dispersal between different agencies and overseers, scarcity and often questionable quality), which poses serious problems and limitations at the implementation of most comprehensive models.

This choice lies under the assumption that empirical models (e.g. RUSLE) will probably perform better than their complex counterparts, since the latter type of models are subject to considerable parameter uncertainty. Moreover, despite their shortcomings (e.g. provide a more simplified approach of the complex mechanisms of soil erosion (detachment-transport-deposition), developed based on regression analysis of local parameters and coefficients and thus having a limited applicability when used in different regions), they can provide a good basis in terms of a preliminary approximation. A GIS assisted approach was used, enhancing the application's accuracy, reliability and computational speed.

The study area was comprised by the Venetikos, Kalamas, Arachthos and upper Acheloos River catchments. These basins were selected on the basis of being some of the most important aquatic systems in Greece, with the corresponding rivers contributing to the regions development, i.e. meeting with the irrigation, water supply and energy production needs, as long as the environmental sustainability. Moreover, forcing input data, discharge and sediment discharge measurements at the catchments' outlet were available giving the opportunity to implement and assess the selected RUSLE models. The paper is organized as follows. A presentation of the catchments, models and methods is presented in Section 2. Results are presented in Section 3, and finally Section 4 states the conclusions of this inter-comparison experiment.

\section{Data and methods}

\subsection{Study area and data}

All catchments are located in northwestern Greece (Fig. 1). They are mainly mountainous, yet display topographical variations throughout their area. They have dense hydrographic networks, elongated shapes and orientation from north to south (apart from the Venetikos River catchment which is almost circular, orienting from east to west), with their climate and hydrological regime being characterized as Mediterranean. 


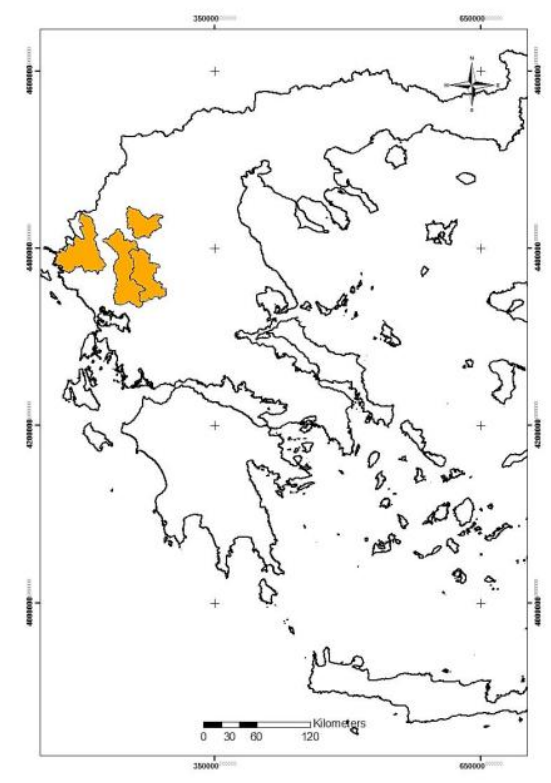

Figure 1. The study area location

The Venetikos River catchment (namely Grevena Bridge), the largest and most important tributary of Aliakmonas River, is located at the Western Macedonia Water District, resting almost entirely over the Grevena Prefecture (Fig. 2(a)). The Kalamas River catchment (separated into two consecutive subcatchments, namely Soulopoulo Bridge and Kioteki) is located at the Epirus Water District, resting over the Thesprotia and loannina Prefectures (Fig. 2(b)). The Upper Acheloos River catchment (namely Avlaki Dam) is located at the $N$ part of the Western Central Greece water district, resting on parts of the Aitoloakarnania, Evrytania, Karditsa, Arta, Trikala and Ioannina Prefectures (Fig. 2(c)). Finally, the Arachthos River catchment (separated into four adjacent subcatchments, namely Arta Bridge, Plaka Bridge, Tsimovo Bridge and Gogo Bridge) is located at the SE part of the Epirus water district, resting on the Arta (mostly) and loannina Prefectures (Fig. 2(d)).

The subcatchments' basic attributes (Area (A), Maximum $\left(H_{\text {max }}\right)$; Minimum $\left(H_{\text {min }}\right)$; Mean $\left(H_{\text {mean }}\right)$ elevation, Mean catchment slope $(\mathrm{J})$, Main stream length (L), Mean annual precipitation (P), Mean annual temperature (T)) are presented in Table 1.

Table 1. Basic subcatchment attributes

\begin{tabular}{cccccccccc}
\hline Subcatchment & $\left.\mathbf{A} \mathbf{( k m}^{2}\right)$ & $\mathbf{H}_{\min }(\mathbf{m})$ & $\mathbf{H}_{\operatorname{mean}}(\mathbf{m})$ & $\mathbf{H}_{\max }(\mathbf{m})$ & $\mathbf{J}(\%)$ & $\mathbf{L}(\mathbf{k m})$ & Period & $\mathbf{P}(\mathbf{m m})$ & $\mathbf{T}\left(^{\mathbf{}} \mathbf{C}\right)$ \\
\hline Grevena Br. ${ }^{2}$ & 855.23 & 437.76 & 1008.71 & 2240.00 & 23.64 & 53.90 & $1965-1982$ & 1015.1 & 9.6 \\
\hline Soulopoulo Br. & 671.45 & 142.03 & 630.08 & 2157.13 & 14.50 & 24.82 & $1987-2002$ & 1224.0 & 14.4 \\
\hline Kioteki & 1489.4 & 0.00 & 549.90 & 2157.13 & 15.00 & 90.18 & & 1226.8 & 11.4 \\
\hline Avlaki Dam & 1354.92 & 379.06 & 1224.73 & 2406.32 & 21.52 & 116.00 & $1965-1984$ & 1696.0 & 12.4 \\
\hline Arta Br. & 1889.69 & 75.02 & 833.53 & 2405.02 & 14.38 & 107.80 & $1965-1976$ & 1543.6 & 12.0 \\
\hline Plaka Br. & 1000.54 & 286.03 & 1047.30 & 2405.02 & 16.11 & 60.00 & & 1487.5 & 11.0 \\
\hline Tsimovo Br. & 646.21 & 394.56 & 1027.71 & 2228.85 & 14.31 & 43.80 & & 1386.3 & 10.7 \\
\hline Gogo Br. & 204.75 & 416.59 & 1293.82 & 2405.02 & 21.01 & 18.60 & & 1723.0 & 7.9 \\
\hline
\end{tabular}

a. Br.: Bridge

The Greek PPC conducted at each of the aforementioned subcatchments' outlets, daily discharge $\left(\mathrm{Q}, \mathrm{m}^{3} \mathrm{~s}^{-1}\right)$ and monthly sediment discharge $\left(\mathrm{Qs}, \mathrm{kg} \mathrm{s}^{-1}\right)$ measurements (as well as simultaneous dischargesediment discharge measurements) (Table 2). 


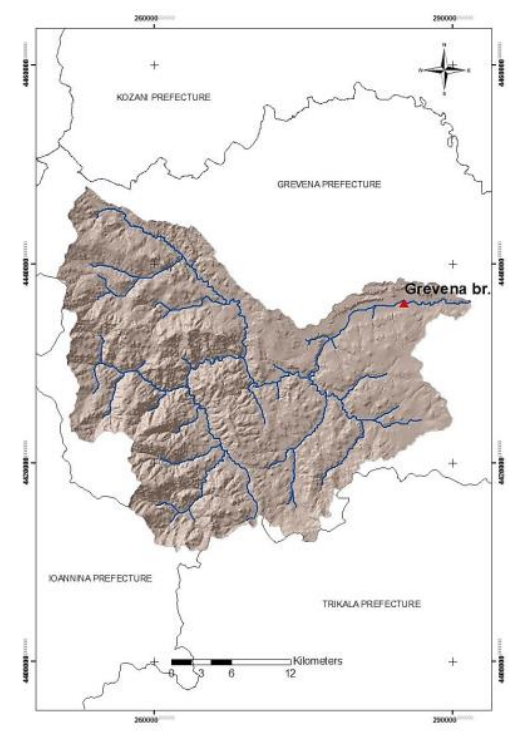

(a) Venetikos River

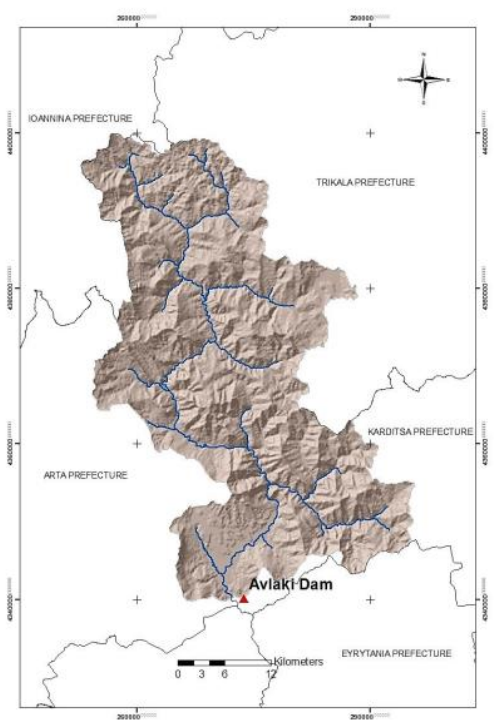

(c) Upper Acheloos River

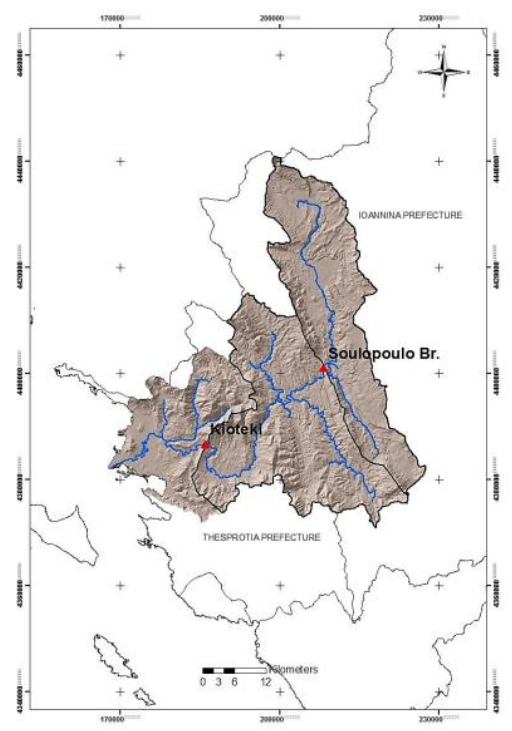

(b) Kalamas River

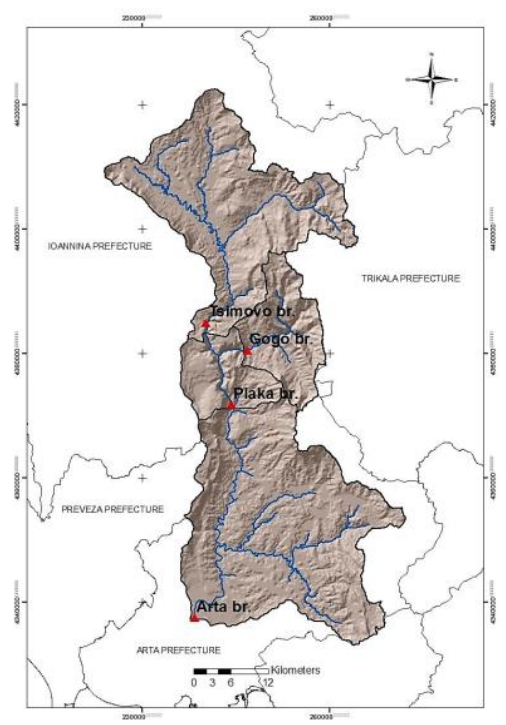

(d) Arachthos River

Figure 2. The study area catchments

Table 2. Discharge/ Sediment Discharge gauging stations

\begin{tabular}{|c|c|c|c|c|c|c|c|c|}
\hline Subcatchment & Service & Prefecture & Lat. (N) & Long. (E) & $H(m)$ & Period & $Q\left(m^{3} s^{-1}\right)$ & Qs $\left(\mathrm{kg} \mathrm{s}^{-1}\right)$ \\
\hline Grevena Br. $^{\mathrm{a}}$ & PPC & Grevena & $21^{\circ} 29^{\prime} 00^{\prime \prime}$ & $40^{\circ} 03^{\prime} 00^{\prime \prime}$ & 468 & $1965-1982$ & 17.9 & 21.5 \\
\hline Soulopoulo Br. & 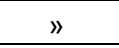 & Ioannina & $20^{\circ} 35^{\prime} 00^{\prime \prime}$ & $39^{\circ} 42^{\prime} 00^{\prime \prime}$ & 160 & 1987-2002 & 15.3 & 27.5 \\
\hline Kioteki & 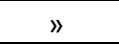 & Thesprotia & $20^{\circ} 20^{\prime} 00^{\prime \prime}$ & $39^{\circ} 34^{\prime} 00^{\prime \prime}$ & 20 & & 31.1 & 88.7 \\
\hline Avlaki Dam & $\|$ & Karditsa & $21^{\circ} 23^{\prime} 00^{\prime \prime}$ & $39^{\circ} 11^{\prime} 00^{\prime \prime}$ & 308.7 & 1965-1984 & 55.2 & 314.6 \\
\hline Arta Br. & 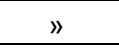 & Arta & $20^{\circ} 58^{\prime} 00^{\prime \prime}$ & $39^{\circ} 09^{\prime} 00^{\prime \prime}$ & 19.0 & 1965-1976 & 58.1 & 1128.7 \\
\hline Plaka Br. & $»$ & Ioannina & $21^{\circ} 10^{\prime} 00^{\prime \prime}$ & $39^{\circ} 27^{\prime} 00^{\prime \prime}$ & 252.0 & & 36.0 & 439.3 \\
\hline Tsimovo Br. & 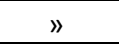 & $»$ & $20^{\circ} 58^{\prime} 00^{\prime \prime}$ & $39^{\circ} 34^{\prime} 00^{\prime \prime}$ & 358.6 & & 19.5 & 140.4 \\
\hline Gogo Br. & 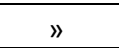 & $"$ & $21^{\circ} 30^{\prime} 00^{\prime \prime}$ & $39^{\circ} 32^{\prime} 00^{\prime \prime}$ & 277.0 & & 10.6 & 56.3 \\
\hline
\end{tabular}

a. Br.: Bridge 


\subsection{The RUSLE model}

The Revised Universal Soil Loss Equation (RUSLE) (Renard et al., 1991; 1994; 1996) was used in order to estimate mean annual soil loss at the aforementioned subcatchments. The model is a simple linear product of six major erosion factors, concerning rainfall, soil characteristics, topography, vegetation cover, and erosion control practices (Equation 1).

\section{$A=R \cdot K \cdot L S \cdot C \cdot P$}

where $A$ is the mean annual soil loss per unit of area $\left(t \mathrm{tha}^{-1} \mathrm{y}^{-1}\right), \mathrm{R}$ is the Rainfall Erosivity Factor (MJ mm $\left.\mathrm{ha}^{-1} \mathrm{~h}^{-1} \mathrm{y}^{-1}\right), \mathrm{K}$ is the Soil Erodibility Factor $\left(\mathrm{t} \mathrm{h} \mathrm{MJ} \mathrm{mm}^{-1}\right.$ ), LS is the Topographic Factor (dimensionless) including slope length factor (dimensionless) and slope steepness factor (dimensionless), $C$ is the cover management factor (dimensionless), and $P$ is the support (or conservation) practice factor (dimensionless).

The RUSLE was developed to incorporate additional research, experiments, data, resources becoming available and a deeper understanding of the erosion process, since the earlier USLE publication (Wischmeier and Smith, 1978). The basic form of the equation has remained the same, but modifications in several of the factors have been made.

These modifications include new (the $R$ factor has been expanded to include the Western United States) and revised (filling of data gaps and a more refined smoothing of the $\mathrm{R}$ iso-erodent map of the Eastern US has also been performed) iso-erodent maps and corrections made to account for rainfall on ponded water, a time-varying (seasonal) approach for soil erodibility factor $(K)$, a new equation to reflect slope length and steepness (slope length $(\mathrm{L})$ and steepness $(\mathrm{S})$ factors have been revised to account for the relation between rill and inter-rill erosion), a sub-factor approach for evaluating the cover-management factor (the $\mathrm{C}$ factor no longer represents seasonal soil-loss ratios; it now represents a continuous function of prior land use, surface cover, crop canopy, surface roughness, and soil moisture) and new conservationpractice values (the factor $P$ has been expanded to include conditions for rangelands, contouring, stripcropping, and terracing) (Renard et al., 1991; 1994).

Despite having several shortcomings and limitations (e.g. soil erosion is approached in a simplified manner by merely multiplying completely different factors, it estimates soil loss caused by rill and/or inter-rill erosion but not by gully or stream-channel erosion, it does not estimate sediment deposition within a catchment nor sediment yield at its outlet, it has low accuracy for individual flood events, being suitable only for predicting long-term averages, it has questionable application and performance on large scale catchments and areas with varying climatic and topographic conditions), RUSLE is one of the most widely accepted and applied empirical models, at least in terms of a preliminary satisfactory approximation.

\section{Results and Discusion}

The methodology followed is comprised, initially, by the inter-annual implementation of the RUSLE model to each of the study area subcatchments (Grevena Bridge/ Soulopoulo Bridge, Kioteki/ Plaka Bridge, Gogo Bridge, Tsimovo Bridge, Arta Bridge/ Avlaki Dam) for the corresponding time periods (Venetikos River: 1965-1982, Kalamas River: 1987-2002, Arachthos River: 1965-1976, Acheloos River: 1965-1984).

The implementation of RUSLE requires the estimation of the model's individual factors ( $R, K, L S, C$ and $P$ ). Due to the lack of detailed precipitation values the Rainfall Erosivity Factor $(R)$ was estimated using the empirical Van der Knijff et al., (2000) equation. The choice was based on a literature review (Sigalos et al., 2010; Zarris et al., 2011). Similarly, the lack of soil properties (granulometry, organic matter content etc.) led to the estimation of the Soil Erodibility Factor (K) using the geological maps of the Greek Institute of Geological and Mining Exploration (IGME) (scale of 1:50 000). A K factor value was assigned to each geological formation, according to the international literature (Panagos et al., 2014). The region's land cover was described based on the CORINE Land Cover 2000 database. Subsequently, a C factor value was assigned to every land use met, following a literature review (Wischmeier and Smith, 1978; Lykoudi and Zarris, 2002; Panagos et al., 2015). The Topographic (LS) factor was estimated based on the Digital 
Elevation Models (DEMs) of all catchments (scale 1:50.000) (created using the Greek Military Geographical Service maps). Its results are in accordance with the corresponding European ones (Panagos et al., 2015). Finally, the $P$ factor was assigned a unit value to all subcatchments, since no information considering the preventing practices followed is available.

Mean annual gross erosion (mean annual soil loss per unit area) was initially calculated ( $t \mathrm{ha}^{-1} \mathrm{y}^{-1}$ ) for each subcatchment. Yet, only a fraction of the sediment produced, will reach their outlet as sediment yield. This fraction is quantified by the sediment delivery ratio (SDR), defined as the ratio of sediment delivered at the catchment's outlet to gross erosion within the catchment.

In the present study SDR was calculated for every subcatchment, using the Renfro (1972) empirical equation (Efthimiou, 2016). SDR was then applied to the subcatchments' mean annual gross erosion (since the model does not consider the deposition processes occurring), estimating sediment yield (transported gross erosion) at their outlet $\left(\mathrm{t} \mathrm{ha}^{-1} \mathrm{y}^{-1}\right)$. The simulated sediment yield results $\left(S \mathrm{SY}_{\mathrm{sim}}\right)$ were cross-evaluated with the observed ones ( $\mathrm{SY}_{\mathrm{obs}}$ ) (estimated considering the sediment discharge measurements recorded by the Greek Public Power Corporation (PPC) at the outlet of each subcatchment), attributing an initial error term value $\left(\Sigma\left(\mathrm{SY}_{\text {sim }}-\mathrm{SY}_{\mathrm{obs}}\right)^{2}\right)$ of $40213.06 \mathrm{t} \mathrm{ha}^{-1}$ (Table 3$)$.

Table 3. $S Y_{\text {sim }}-S Y_{\text {obs }}$ error term, no weighing coefficients

\begin{tabular}{|c|c|c|c|c|c|c|c|c|c|}
\hline & & & & & & PPC & RUSLE & & \\
\hline & $\mathbf{R}$ & K & LS & C & $\mathbf{P}$ & $\begin{array}{c}\text { SYobs } \\
\left(\mathrm{t} \mathrm{ha}^{-1}\right)\end{array}$ & $\begin{array}{c}\mathrm{SY}_{\text {sim }} \\
\left(\mathrm{t} \mathrm{ha}^{-1}\right)\end{array}$ & $\left(S Y_{s i m}-S Y_{o b s}\right)^{2}$ & $\begin{array}{c}\Delta\left(S Y_{\text {sim }}-S Y_{\text {obs }}\right) \\
\left(\mathrm{t} \mathrm{ha}^{-1}\right)\end{array}$ \\
\hline Grevena Br. $^{a}$ & 1153.98 & 0.02 & 33.14 & 0.06 & 1.00 & 7.92 & 5.38 & 6.45 & -2.54 \\
\hline $\begin{array}{c}\text { Soulopoulo } \\
\text { Br. }\end{array}$ & 1523.22 & 0.01 & 26.34 & 0.08 & 1.00 & 12.92 & 3.13 & 95.84 & -9.79 \\
\hline Kioteki & 1557.55 & 0.01 & 35.33 & 0.07 & 1.00 & 18.78 & 4.53 & 203.06 & -14.25 \\
\hline Avlaki Dam & 2281.01 & 0.01 & 91.89 & 0.09 & 1.00 & 73.22 & 52.69 & 421.48 & -20.53 \\
\hline Arta Br. & 1990.71 & 0.02 & 57.70 & 0.08 & 1.00 & 188.37 & 29.15 & 25351.01 & -159.22 \\
\hline Plaka Br. & 1919.76 & 0.02 & 69.01 & 0.09 & 1.00 & 138.47 & 42.97 & 9120.25 & -95.50 \\
\hline Tsimovo Br. & 1826.36 & 0.02 & 58.16 & 0.06 & 1.00 & 68.52 & 29.20 & 1546.06 & -39.32 \\
\hline \multirow[t]{2}{*}{ Gogo Br. } & 2198.61 & 0.02 & 99.10 & 0.18 & 1.00 & 86.75 & 145.66 & 3470.39 & 58.91 \\
\hline & & & & & & & $\Sigma$ & 40213.06 & \\
\hline
\end{tabular}

\section{a. Br.: Bridge}

Subsequently, the model was properly modified (its individual factors $(R, K, L S, C)$ were assigned with a weighing coefficient ( $w_{1}-w_{4}$, respectively), according to their significance), in order to minimize the error term (Table 4).

Table 4. $\mathrm{SY}_{\text {sim }}-\mathrm{SY}_{\text {obs }}$ error term, weighing coefficients considering the PPC measurements

\begin{tabular}{|c|c|c|c|c|c|c|c|c|c|}
\hline & $w_{1}$ & $w_{2}$ & $w_{3}$ & $\mathbf{w}_{4}$ & & & & & \\
\hline & 0.908 & 0.312 & 0.250 & 0.340 & & & & & \\
\hline & & & & & & PPC & Mod. RUSLE & & \\
\hline & $\mathbf{R}$ & K & LS & C & $\mathbf{P}$ & $\begin{array}{c}\mathrm{SY}_{\text {obs }} \\
\left(\mathrm{t} \mathrm{ha}^{-1}\right)\end{array}$ & $\begin{array}{c}\mathrm{SY}_{\text {sim }} \\
\left(\mathrm{t} \mathrm{ha}^{-1}\right) \\
\end{array}$ & $\left(\mathrm{SY}_{\text {sim }}-\mathrm{SY}_{\mathrm{obs}}\right)^{2}$ & $\begin{array}{c}\Delta\left(S Y_{\text {sim }}-S Y_{\text {obs }}\right) \\
\left(\mathrm{t} \mathrm{ha}^{-1}\right)\end{array}$ \\
\hline Grevena Br. $^{a}$ & 1153.98 & 0.02 & 33.14 & 0.06 & 1.00 & 7.92 & 36.65 & 825.56 & 28.73 \\
\hline $\begin{array}{c}\text { Soulopoulo } \\
\text { Br. }\end{array}$ & 1523.22 & 0.01 & 26.34 & 0.08 & 1.00 & 12.92 & 34.66 & 472.74 & 21.74 \\
\hline Kioteki & 1557.55 & 0.01 & 35.33 & 0.07 & 1.00 & 18.78 & 38.83 & 401.82 & 20.05 \\
\hline Avlaki Dam & 2281.01 & 0.01 & 91.89 & 0.09 & 1.00 & 73.22 & 85.83 & 158.92 & 12.61 \\
\hline Arta Br. & 1990.71 & 0.02 & 57.70 & 0.08 & 1.00 & 188.37 & 62.56 & 15829.49 & -125.82 \\
\hline Plaka Br. & 1919.76 & 0.02 & 69.01 & 0.09 & 1.00 & 138.47 & 72.34 & 4373.16 & -66.13 \\
\hline Tsimovo Br. & 1826.36 & 0.02 & 58.16 & 0.06 & 1.00 & 68.52 & 63.92 & 21.18 & -4.60 \\
\hline \multirow[t]{2}{*}{ Gogo Br. } & 2198.61 & 0.02 & 99.10 & 0.18 & 1.00 & 86.75 & 148.83 & 3854.20 & 62.08 \\
\hline & & & & & & & $\Sigma$ & 25937.07 & \\
\hline
\end{tabular}

a. Br.: Bridge 
Following the same methodology new simulated sediment yield values $\left(\mathrm{SY}_{\text {sim }}\right)$, and an improved error term value of $25937.07 \mathrm{t} \mathrm{ha}^{-1}$ were attributed. The result was quite satisfactory, not only by reducing the error term value in half, but also by reducing the individual differences $\left(\Delta\left(\mathrm{SY}_{\mathrm{sim}}-\mathrm{SY} \mathrm{obs}_{\mathrm{s}}\right)\right)$ between simulated and observed sediment yield at most catchments.

In Greece, the ambiguous reliability of sediment discharge measurements (infrequent and often inadequate, having a random and unsystematic character, concerning only the suspension load), poses a serious problem for the accurate assessment of erosion. Such measurements were conducted only by the Greek PPC, mainly at the designing stage of reservoir construction projects and often stopped after the project was finished.

All of the above (along with the lack of such measurements at Kioteki and Soulopoulo Bridge) led to their replacement by simulated ones. The latter, were estimated by the implementation of observed daily discharge values (PPC) to the representative sediment discharge rating curve construction method of each subcatchment (Grevena Bridge/ Soulopoulo Bridge/ Kioteki/ Avlaki Dam: Broken line interpolation, Arta Bridge/ Plaka Bridge/ Gogo Bridge: Linear regression of the log-transformed variables (Ferguson correction), Tsimovo Bridge: different ratings for the dry-wet season of the year). Henceforward, they will be considered as observed (Q-Qs) (Efthimiou, 2016). It is noted that, the PPC measurements remain indirectly involved to the procedure, since they were (apart from the Kioteki and Soulopoulo Bridge) the benchmark for choosing the aforementioned construction methods.

The model was anew modified (different weighing coefficients $\left.\left(w_{1}-w_{4}\right)\right)$ and implemented to each subcatchment. The results were cross-evaluated with the "new" observed ones, attributing an error term value of $5834.78 \mathrm{t} \mathrm{ha}^{-1}$ (Table 5). The result was significantly improved, reduced to almost $1 / 4$ of the latter and to $1 / 7$ of the original value. The individual differences between simulated and observed sediment yield values were also reduced in most of the subcatchments.

Table 5. $\mathrm{SY}_{\text {sim }}-\mathrm{SY}_{\text {obs }}$ error term, weighing coefficients considering the rating curves estimations

\begin{tabular}{|c|c|c|c|c|c|c|c|c|c|}
\hline & w1 & w2 & w3 & w4 & & & & & \\
\hline & 0.874 & 0.338 & 0.223 & 0.324 & & & & & \\
\hline & & & & & & Q-Qs & Mod. RUSLE & & \\
\hline & $\mathbf{R}$ & K & LS & C & $\mathbf{P}$ & $\begin{array}{l}\text { SY obs } \\
\left(\mathrm{t} \mathrm{ha}^{-1}\right)\end{array}$ & $\begin{array}{l}\mathrm{SY}_{\operatorname{sim}} \\
\left(\mathrm{t} \mathrm{ha}^{-1}\right)\end{array}$ & $\left(S Y_{\text {sim }}-S Y_{o b s}\right)^{2}$ & $\begin{array}{c}\Delta\left(\mathrm{SY}_{\text {sim }}-\mathrm{SY}_{\text {obs }}\right) \\
\left(\mathrm{t} \mathrm{ha}^{-1}\right)\end{array}$ \\
\hline Grevena Br. $^{\mathrm{a}}$ & 1153.98 & 0.02 & 33.14 & 0.06 & 1.00 & 5.49 & 24.90 & 376.73 & 19.41 \\
\hline Soulopoulo Br. & 1523.22 & 0.01 & 26.34 & 0.08 & 1.00 & 12.92 & 22.57 & 93.11 & 9.65 \\
\hline Kioteki & 1557.55 & 0.01 & 35.33 & 0.07 & 1.00 & 18.78 & 25.43 & 44.21 & 6.65 \\
\hline Avlaki Dam & 2281.01 & 0.01 & 91.89 & 0.09 & 1.00 & 49.64 & 54.58 & 24.34 & 4.93 \\
\hline Arta Br. & 1990.71 & 0.02 & 57.70 & 0.08 & 1.00 & 93.41 & 40.59 & 2790.50 & -52.83 \\
\hline Plaka Br. & 1919.76 & 0.02 & 69.01 & 0.09 & 1.00 & 87.79 & 46.70 & 1688.64 & -41.09 \\
\hline Tsimovo Br. & 1826.36 & 0.02 & 58.16 & 0.06 & 1.00 & 28.86 & 41.78 & 166.98 & 12.92 \\
\hline \multirow[t]{2}{*}{ Gogo Br. } & 2198.61 & 0.02 & 99.10 & 0.18 & 1.00 & 68.29 & 93.79 & 650.26 & 25.50 \\
\hline & & & & & & & $\Sigma$ & 5834.78 & \\
\hline
\end{tabular}

a. Br.: Bridge

At both approaches, the weighing coefficients denoted the comparatively greater significance of the Rainfall erosivity factor $(R)$ against all others equation factors $(K, L S, C, P)$ to the soil erosion phenomenon. In order to validate its reliability, the model's final modification was moreover implemented to all subcatchments at both time scales (annual, inter-annual), with the differences between simulated (mod. RUSLE, RUSLE) and observed (PPC, rating curves) sediment yield values being assessed. The modified RUSLE performed very well at some subcatchments (Kioteki, Soulopoulo Bridge, Gogo Bridge) while not as well at others (Grevena Bridge, Plaka Bridge). At Avlaki Dam, Arta Bridge, Tsimovo Bridge, the original form slightly prevailed (greater uncertainty when implemented annually), but there is no marked differentiation, which leads effortlessly to the rejection of the methodology (Table 6).

The inconsistent behavior is mainly attributed to the relatively small set of hydrological basins used for the determination of the weighing coefficients, their specific characteristics (hydrological regime, climate, soil type, morphology, soil cover) as well as the overall methodology errors (model implementation, 
sediment discharge field measurements (PPC) - as mentioned previously, inherent rating curves methodology shortcomings - e.g. simultaneous measurements of river discharge and sediment discharge are mainly conducted only in low-flow periods, thus any extrapolation for wash loads at the time of low frequency-high magnitude flood flows will generally give misleading results; estimates of sediment yield based on rating curve calculations will in most cases involve greater error than those obtained from direct measurements, and this can be ascribed primarily to the scatter associated with the rating relationship etc). The study flowchart is presented at Fig. 3.

Table 6. Modified RUSLE aggregated performance

\begin{tabular}{|c|c|c|c|c|c|}
\hline & & \multicolumn{2}{|c|}{ Inter-annual } & \multicolumn{2}{|c|}{ Annual } \\
\hline & & RUSLE & Mod. RUSLE & RUSLE & Mod. RUSLE \\
\hline Venetikos R. & Grevena $\mathrm{Br} .^{\mathrm{a}}$ & $\bullet \bullet \bullet$ & - & $\bullet \bullet \bullet$ & - \\
\hline \multirow[t]{2}{*}{ Kalamas R. } & Soulopoulo $\mathrm{Br}$. & - & $\bullet \bullet \bullet$ & - & $\bullet \bullet \bullet$ \\
\hline & Kioteki & - & $\bullet \bullet \bullet$ & - & $\bullet \bullet \bullet$ \\
\hline Acheloos R. & Avlaki Dam & $\bullet \bullet$ & $\bullet$ & $\bullet \bullet$ & $\bullet$ \\
\hline \multirow[t]{4}{*}{ Arachthos R. } & Arta Br. & & $\approx$ & & $\approx$ \\
\hline & Plaka Br. & $\bullet \bullet \bullet$ & - & & $\approx$ \\
\hline & Tsimovo $\mathrm{Br}$. & & $\approx$ & & $\approx$ \\
\hline & Gogo Br. & - & $\bullet \bullet \bullet$ & - & $\bullet \bullet \bullet$ \\
\hline
\end{tabular}

a. Br.: Bridge

$\bullet \bullet \bullet, \bullet \bullet, \bullet,-$ : performance scale

$\approx$ : similar performance

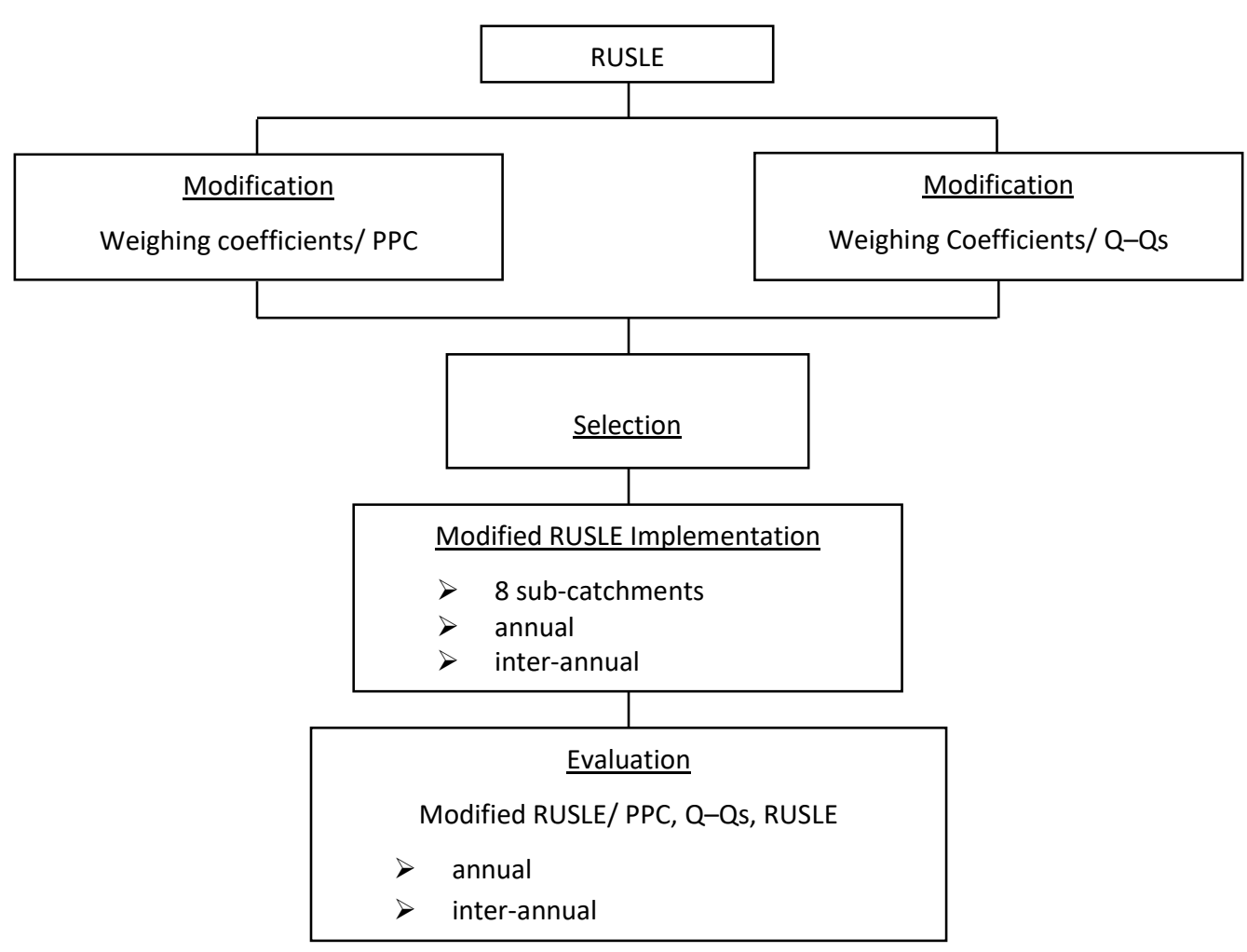

Figure 3. Study flowchart

\subsection{Inter-annual implementation}

The model's inter-annual sediment discharge (QS) and yield (SY) results are presented in Table 7. 
At Grevena Bridge, modified RUSLE overestimated the observed sediment yield and discharge results (either measured (PPC) or estimated (Q-Qs)). The model's original form performed better, simulating quite satisfactory the initially considered observed values (PPC), while having an exceptional adaptation to the rating curve one. At both Soulopoulo Bridge and Kioteki subcatchments, RUSLE significantly underestimated the results. On the contrary, its modified form performed much better, simulating excellently the observed values (they are identical (PPC, Q-Qs) since no sediment discharge measurements were available). At Avlaki Dam, modified RUSLE significantly underestimated the results, simulating better (comparatively) the estimated (Q-Qs) observed values. The model's original form performed much better, having an exceptional adaptation to the estimated values. At Arta Bridge and Plaka Bridge, both forms performed quite similarly (especially at Arta Bridge), significantly underestimating the measured (PPC) observed results, yet being closer to the estimated ones (Q-Qs).

Table 7. Aggregated inter-annual sediment yield and sediment discharge results

\begin{tabular}{|c|c|c|c|c|}
\hline River & Subcatchment & Model & Qs $\left(\mathrm{kg} \mathrm{s}^{-1}\right)$ & $S Y\left(t \mathrm{ha}^{-1}\right)$ \\
\hline \multirow[t]{4}{*}{ Venetikos R. } & Grevena Br. $^{a}$ & PPC & 21.48 & 7.92 \\
\hline & & Q-Qs curve & 14.89 & 5.49 \\
\hline & & RUSLE & 14.59 & 5.38 \\
\hline & & Mod. RUSLE & 36.09 & 13.31 \\
\hline \multirow[t]{8}{*}{ Kalamas R. } & Soulopoulo Br. & PPC & 27.50 & 12.92 \\
\hline & & Q-Qs curve & 27.50 & 12.92 \\
\hline & & RUSLE & 6.66 & 3.13 \\
\hline & & Mod. RUSLE & 26.58 & 12.48 \\
\hline & Kioteki & PPC & 88.70 & 18.78 \\
\hline & & Q-Qs curve & 88.70 & 18.78 \\
\hline & & RUSLE & 21.40 & 4.53 \\
\hline & & Mod. RUSLE & 71.59 & 15.16 \\
\hline \multirow[t]{4}{*}{ Acheloos R. } & Avlaki Dam & PPC & 314.61 & 73.22 \\
\hline & & Q-Qs curve & 215.18 & 50.08 \\
\hline & & RUSLE & 226.38 & 52.69 \\
\hline & & Mod. RUSLE & 149.63 & 34.83 \\
\hline \multirow[t]{16}{*}{ Arachthos R. } & Arta Br. & PPC & 1128.75 & 188.37 \\
\hline & & Q-Qs curve & 559.76 & 93.41 \\
\hline & & RUSLE & 174.68 & 29.15 \\
\hline & & Mod. RUSLE & 152.45 & 25.44 \\
\hline & Plaka Br. & PPC & 439.33 & 138.47 \\
\hline & & Q-Qs curve & 278.53 & 87.79 \\
\hline & & RUSLE & 136.34 & 42.97 \\
\hline & & Mod. RUSLE & 91.51 & 28.84 \\
\hline & Tsimovo Br. & PPC & 140.40 & 68.52 \\
\hline & & Q-Qs curve & 59.14 & 28.86 \\
\hline & & RUSLE & 59.83 & 29.20 \\
\hline & & Mod. RUSLE & 50.62 & 24.70 \\
\hline & Gogo Br. & PPC & 56.33 & 86.75 \\
\hline & & Q-Qs curve & 44.34 & 68.29 \\
\hline & & RUSLE & 94.57 & 145.66 \\
\hline & & Mod. RUSLE & 42.07 & 64.80 \\
\hline
\end{tabular}

\section{a. Br.: Bridge}

At Tsimovo Bridge, both models attributed quite similar results, significantly underestimating the measured (PPC) observed results, while performing exceptionally well concerning the estimated ones ( $Q-$ Qs), with the original form attributing almost identical values. At Gogo Bridge, modified RUSLE results are significantly underestimated compared to the ones attributed by the original form. Modified RUSLE simulated quite satisfactory the observed values, especially the estimated ones (Q-Qs). 
Validation can also be achieved by correlating the simulated sediment discharge values of all basins, against the corresponding observed ( $Q-Q s)$ ones, considering the coefficient of determination $\left(R^{2}\right)$. The modified model performed exceptionally well.

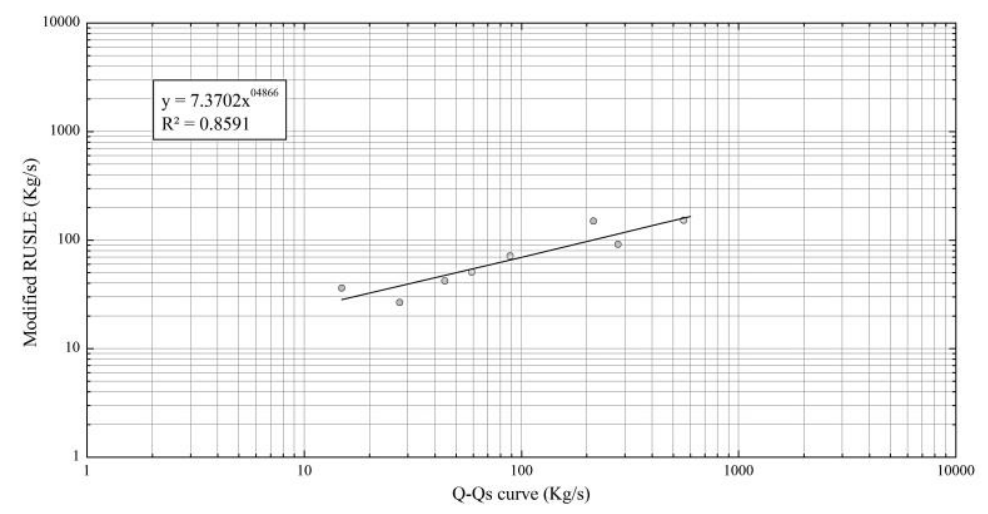

Figure 4. Correlation between observed (Q-Qs) and simulated (Mod. RUSLE) inter-annual sediment discharge $\left(\mathrm{kg} \mathrm{s}^{-1}\right)$ values

Concerning the phenomenon's spatial distribution, mean annual gross erosion (soil loss) per unit area was initially estimated (t ha ${ }^{-1} \mathrm{y}^{-1}$ ) for both models, at all subcatchments (Fig. 5; Fig. 6). Since precipitation intensity, bed rock properties, slope relief and soil cover characteristics were identical, denoting that sediment "production" sources throughout each subcatchment remain the same, the spatial differences were attributed to the models' range of numeric results (Table 8) and their corresponding classification. It is noted that although the RUSLE attributed significantly higher maximum values than its modified form (thus, the intermediate ones cannot be properly projected), mean values did not deviate as much (being overestimated at the Grevena Bridge, Soulopoulo Bridge and Kioteki subcatchments).

Table 8. Average Annual Gross Erosion per unit area ( $\left.\mathrm{t} \mathrm{ha} \mathrm{a}^{-1} \mathrm{y}^{-1}\right)$.

\begin{tabular}{cccccc}
\hline River & SubCatchment & Model & Min & Mean & Max \\
\hline Venetikos R. & Grevena Br. ${ }^{\text {a }}$ & Mod. RUSLE & 1.04 & 58.08 & 383.31 \\
\hline & & RUSLE & 0.00 & 23.49 & $3,446.42$ \\
\hline Kalamas R. & Soulopoulo Br. & Mod. RUSLE & 1.56 & 52.60 & 457.24 \\
\hline & & RUSLE & 0.00 & 13.19 & $3,926.68$ \\
\hline & Kioteki & Mod. RUSLE & 1.64 & 63.88 & 458.66 \\
\hline Acheloos R. & & RUSLE & 0.00 & 21.48 & $4,433.08$ \\
\hline & Avlaki Dam & Mod. RUSLE & 3.11 & 162.97 & 986.73 \\
\hline & & RUSLE & 0.00 & 246.57 & $15,405.91$ \\
\hline & Arta Br. & Mod. RUSLE & 3.20 & 124.90 & 679.49 \\
\hline & & RUSLE & 0.00 & 143.11 & $10,014.65$ \\
\hline & Plaka Br. & Mod. RUSLE & 3.73 & 128.88 & 687.26 \\
\hline & & RUSLE & 0.00 & 192.02 & $10,169.62$ \\
\hline & Tsimovo Br. & Mod. RUSLE & 3.75 & 103.49 & 512.15 \\
\hline & Rog $\mathrm{Br}$. & Mod. RUSLE & 0.00 & 122.33 & $5,621.86$ \\
\hline & & RUSLE & 0.00 & 229.06 & 719.73 \\
\hline & & 514.87 & $10,761.00$ \\
\hline
\end{tabular}

a. Br.: Bridge 


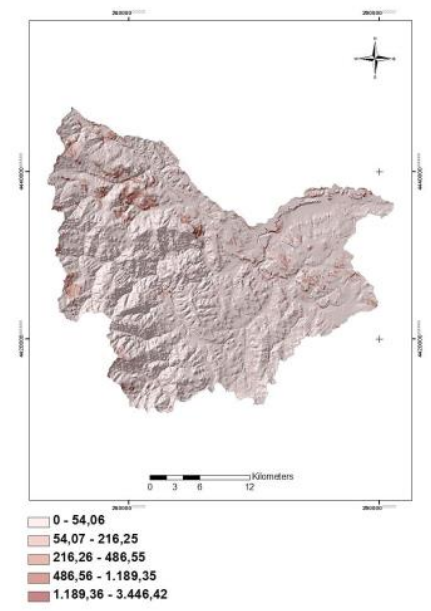

(a) Grevena Bridge

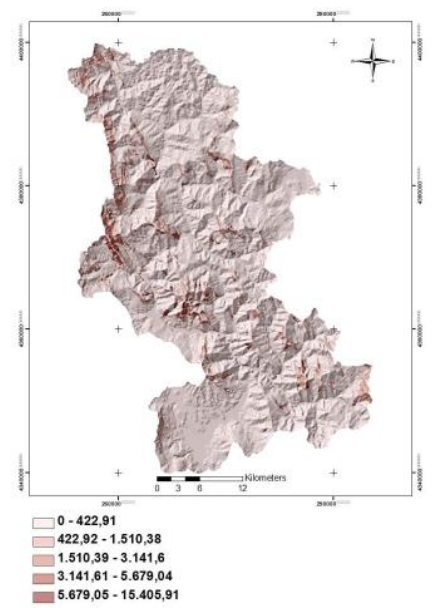

(d) Avlaki Dam

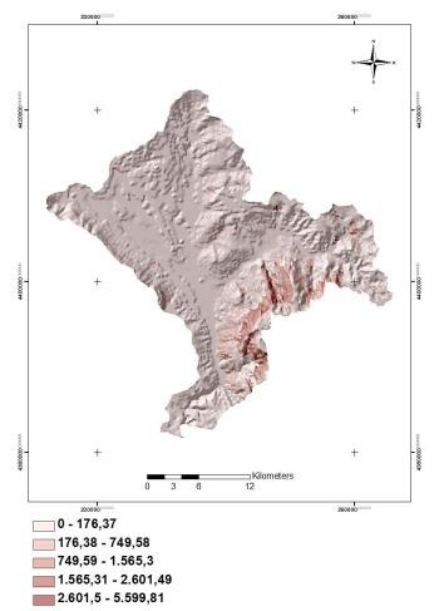

(g) Tsimovo Bridge

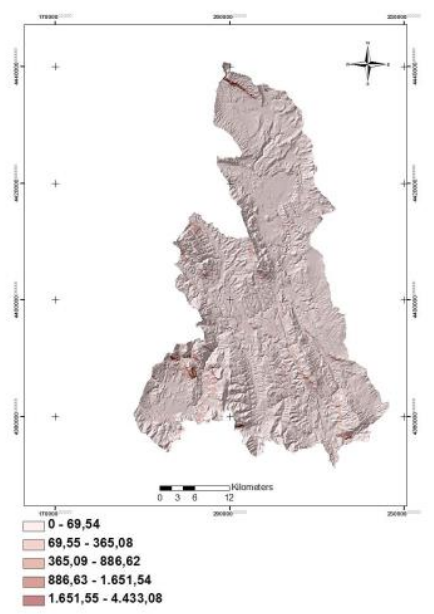

(b) Kioteki

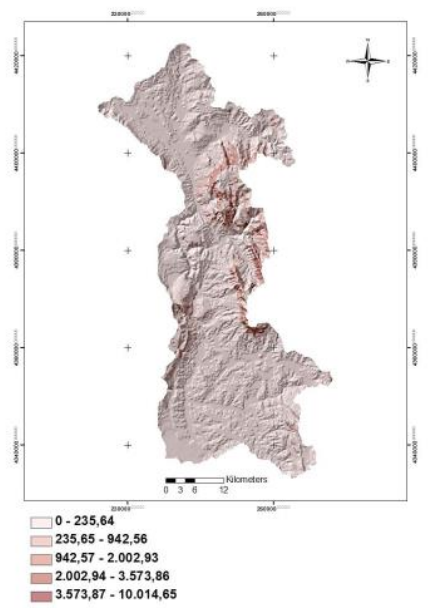

(e) Arta Bridge

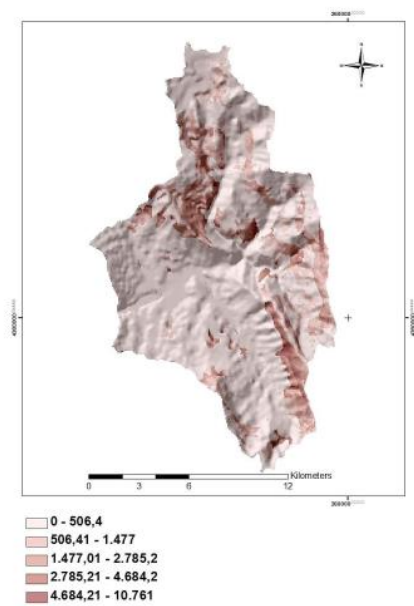

(h) Gogo Bridge

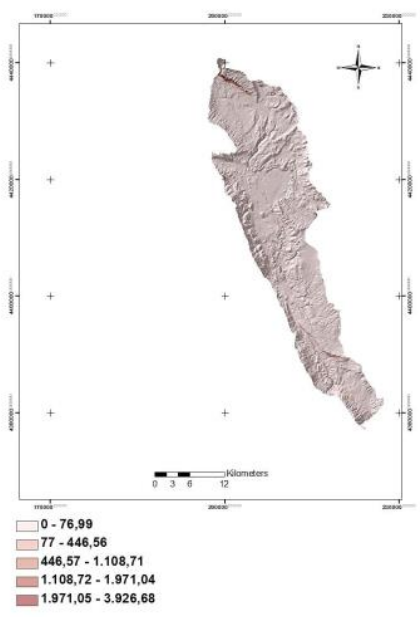

(c) Soulopoulo Bridge

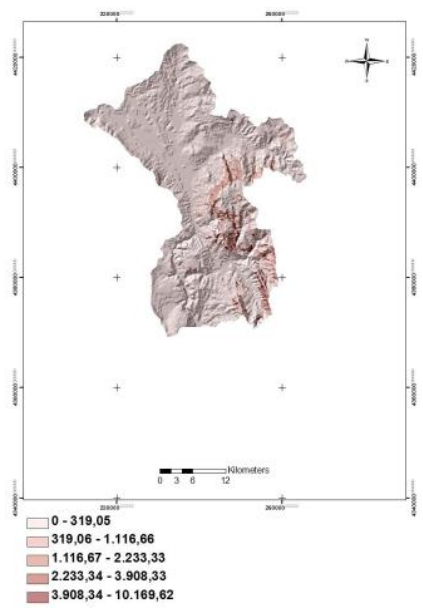

(f) Plaka Bridge

Figure 5. Soil loss per unit area ( $t \mathrm{ha}^{-1} \mathrm{y}^{-1}$ ) based on the RUSLE model 


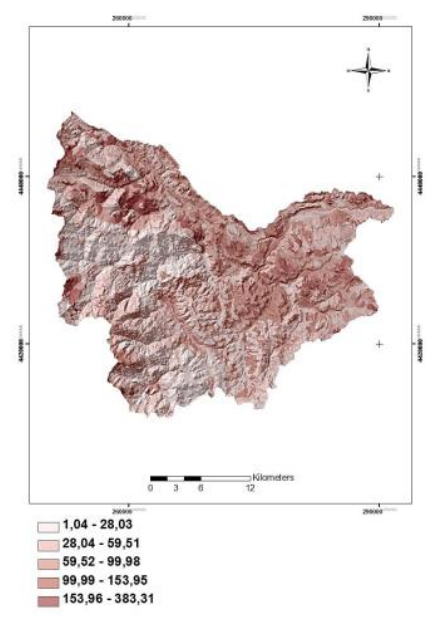

(a) Grevena Bridge

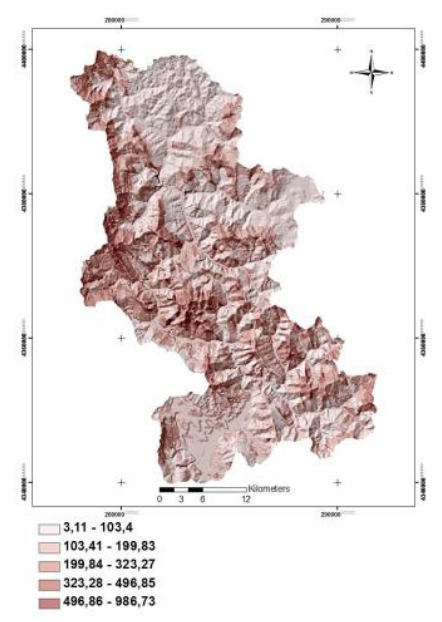

(d) Avlaki Dam

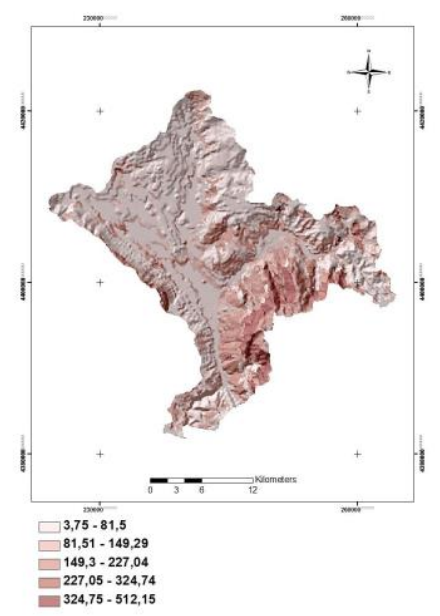

(g) Tsimovo Bridge

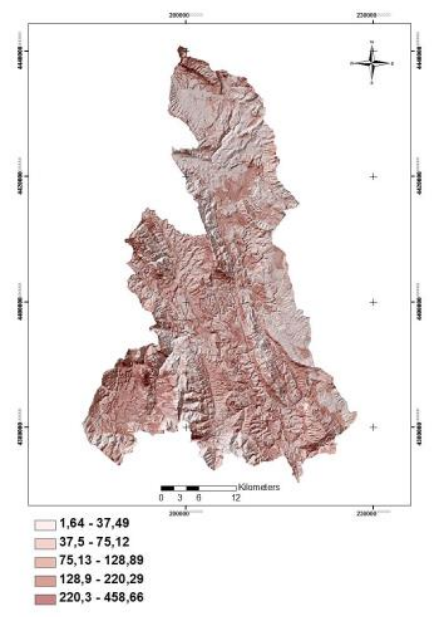

(b) Kioteki

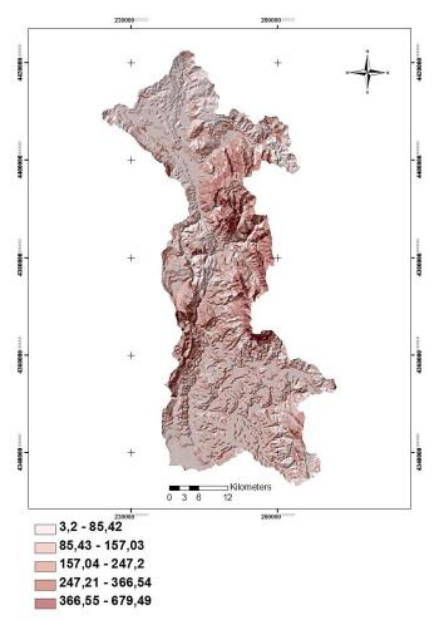

(e) Arta Bridge

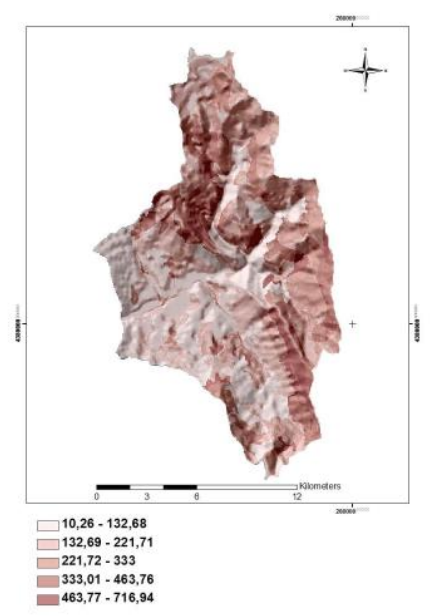

(h) Gogo Bridge

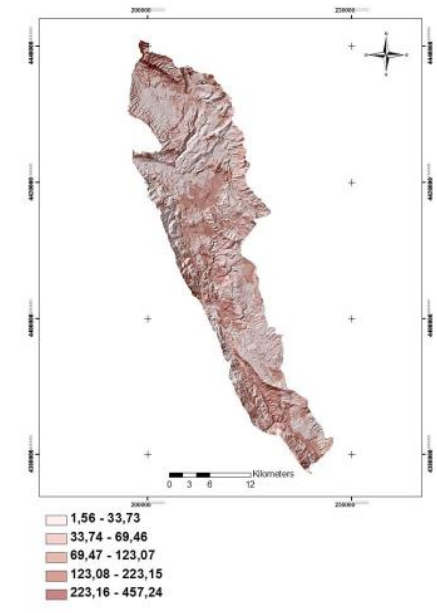

(c) Soulopoulo Bridge

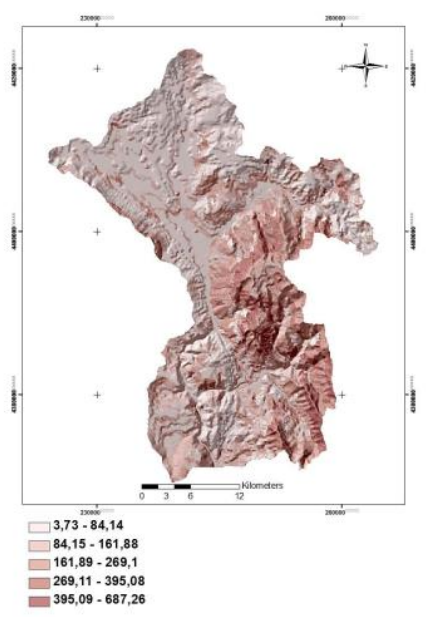

(f) Plaka Bridge

Figure 6. Soil loss per unit area $\left(\mathrm{t} \mathrm{ha} \mathrm{a}^{-1} \mathrm{y}^{-1}\right)$ based on the modified RUSLE model 


\subsection{Annual implementation}

The deviation (\%) between observed (PPC, Q-Qs) and simulated (original and modified RUSLE) annual sediment yield $\left(\mathrm{t} \mathrm{ha}^{-1}\right)$ values is presented in Fig. 7.

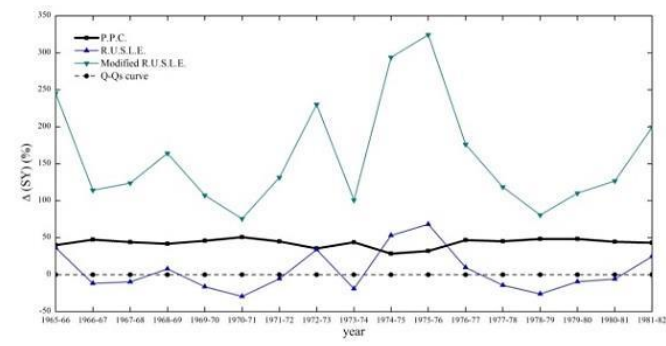

(a) Grevena Bridge

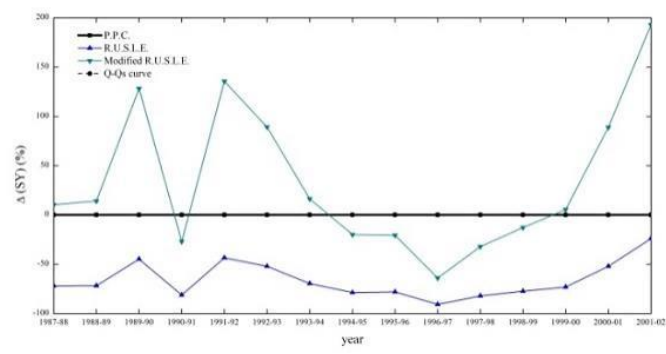

(c) Soulopoulo Bridge

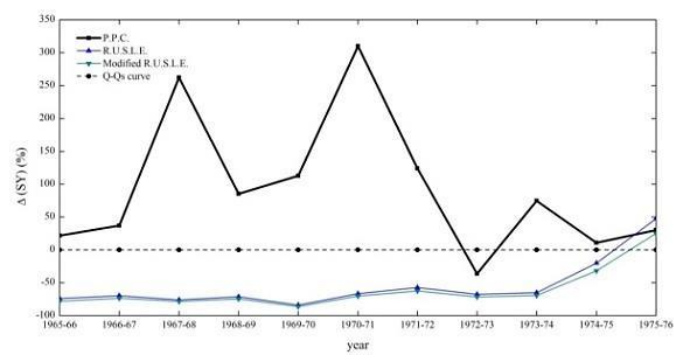

(e) Arta Bridge

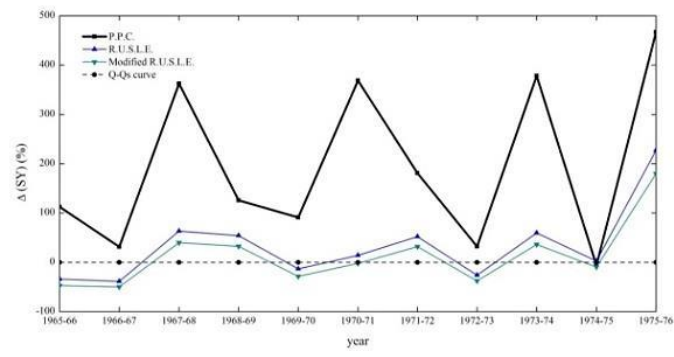

(g) Tsimovo Bridge

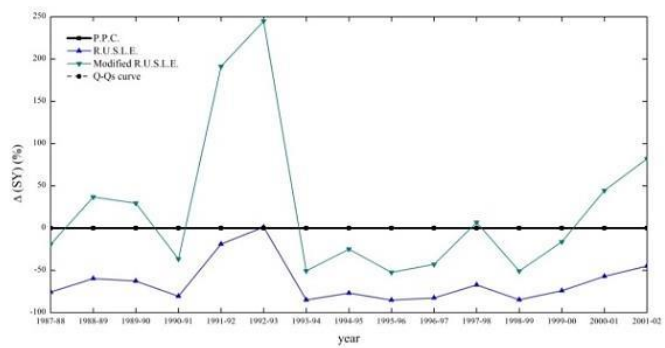

(b) Kioteki

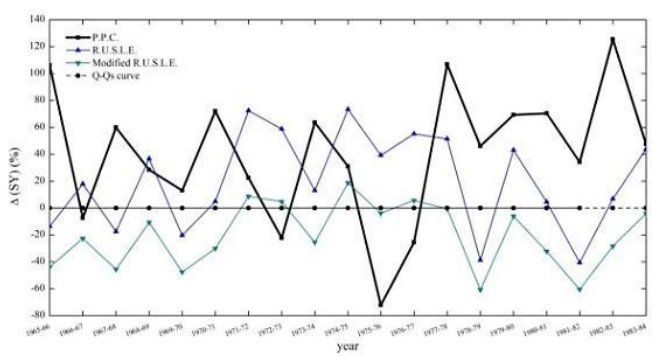

(d) Avlaki Bridge

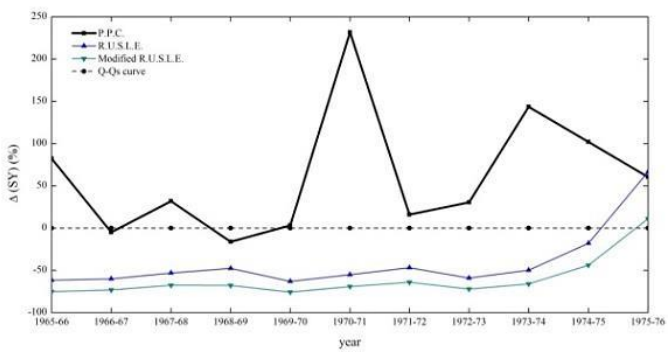

(f) Plaka Bridge

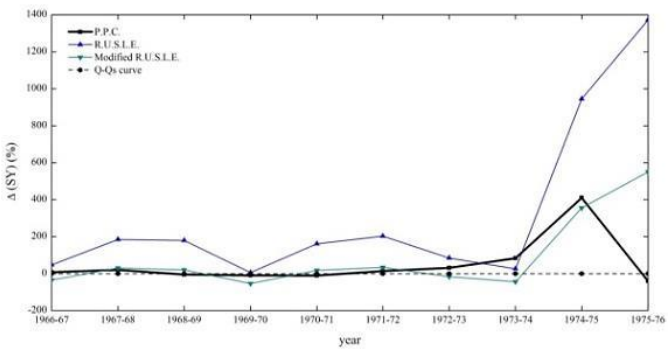

(h) Gogo Bridge

Figure 7. Deviation (\%) between observed (PPC, Q-Qs) and simulated (original and modified RUSLE) annual sediment yield $\left(\mathrm{t} \mathrm{ha}^{-1}\right)$ values 
Concerning the estimated observed (Q-QS) sediment yield, modified RUSLE attributed significantly overestimated results at Grevena Bridge (Fig. 7(a)) throughout the entire time period. The model's original form performed inconsistently, having an annual fluctuation around them, yet approximated them much better. Concerning the measured observed (PPC) values, modified RUSLE also overestimated the results. The original form, despite underestimating the results (apart from the years 1974-75, 1975-76) performed better throughout the entire time period.

At Kioteki (Fig. 7(b)) RUSLE underestimated the estimated observed (Q-Qs) results throughout the entire time period. The modified form, despite having an inconsistent behavior, simulated them more accurately.

At Soulopoulo Bridge (Fig. 7(c)) the models performed similarly to Kioteki subbasin.

Both forms were characterized by inconsistent behavior at Avlaki Dam (Fig. 7(d)), with the attributed values having a small per year fluctuation. RUSLE approximated better the estimated observed (Q-Qs) sediment yield values at the begging and end of the corresponding time period (where the modified form underestimated them), while the modified form at the mid-period (where the original form overestimated them).

At Arta Bridge (Fig. 7(e)) both forms attributed almost identical results (underestimation) throughout the entire time period, having an almost null annual fluctuation. The underestimation decreases at the end of the period. The results were improved, compared to those attributed considering the measured observed (PPC) values.

At Plaka Bridge (Fig. 7(f)) the models performed similarly to the Arta Bridge subcatchment. The original form seems to approximate slightly better the estimated observed (Q-Qs) sediment yield values.

At Tsimovo Bridge (Fig. 7(g)) the models performed similarly to the Arta Bridge and Plaka Bridge subcatchments. Concerning the estimated observed (Q-Qs) values, both models behaved inconsistently, without anyone being clearly superior. The results were improved, compared to those attributed considering the measured observed (PPC) values.

Finally, at Gogo Bridge (Fig. 7(h)) the original form overestimated the estimated observed (Q-Qs) sediment yield results. Modified RUSLE performed inconsistently, having a small per year fluctuation, yet simulating better the corresponding results. It is noted that until the year 1972-73 the observed results (PPC, Q-Qs) are almost identical, while thereafter despite the difference among them, they retain the same trend.

\section{Conclusions}

The study aims to modify the Revised Universal Soil Loss Equation (RUSLE), in order to improve its performance at mountainous, Mediterranean catchments. The study area included the catchments of Venetikos River (Grevena Bridge), Kalamas River (divided into two consecutive subcatchments, namely Soulopoulo Bridge and Kioteki), Arachthos River (divided into four adjacent subcatchments, namely Plaka Bridge, Gogo Bridge, Tsimovo Bridge and Arta Bridge) and Acheloos River (Avlaki Dam), located at NW Greece.

The model was initially implemented inter-annually to each of the study area subcatchments. Subsequently, it was consecutively modified (its factors were assigned with a weighing coefficient, at first in relation to the PPC measurements and then in relation to the rating curves estimations) and anew implemented to all subcatchments both annually and inter-annually. The results were compared to the ones attributed by the original equation, as long as the observed measurements, at both time scales.

Overall, the weighing coefficients assignment caused the reduction of the error term numeric value, from $40213.06 \mathrm{t} \mathrm{ha}^{-1}$ (no coefficients) to $25937.07 \mathrm{t} \mathrm{ha}^{-1}$ (coefficients assigned in relation to the PPC measurements) to $5834.78 \mathrm{tha}^{-1}$ (coefficients assigned in relation to the rating curves (Q-Qs) estimations), as long as the individual differences between simulated and observed sediment discharge values per hydrological catchment. 
The model performed very well at some basins (Kioteki, Soulopoulo Bridge, Gogo Bridge) while not so well at others (Venetikos River, Plaka Bridge). At the Avlaki Dam, Arta Bridge, Tsimovo Bridge, the original form slightly prevailed (greater uncertainty when implemented annually), but there was no marked differentiation, leading effortlessly to the rejection of the methodology. The inconsistent behavior is mainly attributed to the relatively small set of hydrological basins used for the determination of the weighing coefficients, their specific characteristics (hydrological regime, climate, soil type, morphology, soil cover) as well as the overall methodology errors (model implementation, sediment discharge field measurements (PPC), inherent rating curves methodology shortcomings).

\section{References}

Blinkov I. and Kostadinov S. (2010), Applicability of Various Erosion Risk Assessment Methods for Engineering Purposes. BALWOIS 2010 Conference, Ohrid, Republic of Macedonia. 25-29 May, 2010.

Bosco C., Rusco E., Montanarella L. and Panagos P. (2009), Soil erosion in the Alpine area: risk assessment and climate change, Studi Trent Sci Nat, 85, 117-123.

Efthimiou N., Lykoudi E. and Karavitis C. (2014), Soil erosion assessment using the RUSLE model and GIS, European Water, 47, 15-30.

Efthimiou N. (2016), Developing strategies for estimating sediment yield by using Decision Support Systems at mountainous hydrological catchments, Ph.D. Dissertation, Agricultural University of Athens. (In Greek).

Gavrilovic S. (1962), A method for estimating the average annual quantity of sediments according to the potency of erosion. Faculty of Forestry, no. 26, p. 151-168. (In Serbian).

Knisel W.G. (1980). CREAMS: a field scale model for chemicals, runoff and erosion from agricultural management systems. USDA Conservation Research Report No. 26, USDA-ARS, Washington, D.C.

Lykoudi E. and Zarris D. (2002). Identification of regions with high risk of soil erosion in the island of Cephalonia using the Universal Soil Loss Equation. Proceedings of the 6th National Conference of the Geological Society of Greece, Thessaloniki, Greece, Volume II, pp 412-419. (In Greek)

Nearing M.A., Foster G.R., Lane L.J. and Finkner S.C. (1989), A process-based soil erosion model for USDA: water erosion prediction project technology, Transactions of the ASAE, 32, 1587-1593.

Panagos P., Meusburger K., Ballabio C., Borrelli P. and Alewell C. (2014), Soil erodibility in Europe: A high-resolution dataset based on LUCAS, Science of the Total Environment, 479-480, 189-200.

Panagos P., Borrelli P., Meusburger C., Alewell C., Lugato E. and Montanarella L. (2015), Estimating the soil erosion cover-management factor at European scale, Land use policy journal, 48C, 38-50, doi:10.1016/j.landusepol.2015.05.021.

Panagos P., Borrelli P. and Meusburger K. (2015), A New European Slope Length and Steepness Factor (LS-Factor) for Modeling Soil Erosion by Water, Geosciences, 5, 117-126.

Renard K.G., Foster G.R., Weesies G.A. and Porter J.P. (1991), RUSLE: Revised Universal Soil Loss Equation, J.Soil Water Conserv, 46(1), 30-33.

Renard K.G., Foster G.R., Yoder D.C. and McCool D.K. (1994), RUSLE revisited: Status, questions, answers, and the future, Journal of Soil and Water Conservation, 49(3), 213-220.

Renard K.G., Foster G.R., Weesies G.A., McCool D.K. and Yoder D.C. (1996), Predicting Soil Erosion by Water: A Guide to Conservation Planning with the Revised Universal Soil Loss Equation. Agriculture Handbook No. 703, US Department of Agriculture, 384p.

Renfro G.W. (1972). Use of erosion equations and sediment delivery ratios for predicting sediment yield, In: Sediment yield workshop: Present and prospective technology for predicting sediment yield and sources Proceedings USDA Sedim. Labor. Oxford, Mass. USA, pp. 33-45.

Salvati L., Kosmas C., Kairis O., Karavitis C., Acikalin S., Belgacem A., Solé-Benet A., Chaker M., Fassouli V., Gokceoglu C., Gungor H., Hessel R., Khatteli H., Kounalaki A., Laouina A., Ocakoglu F., Ouessar M., Ritsema C., Sghaier M., Sonmez H., Taamallah H., Tezcan L. and de Vente J. (2014), Unveiling soil degradation and desertification risk in the Mediterranean basin: a data mining analysis of the relationships between biophysical and socioeconomic factors in agro-forest landscapes, Journal of Environmental Planning and Management, doi:10.1080/09640568.2014.958609. 
Sigalos G., Loukaidi V., Dasaklis S. and Alexouli-Livaditi A. (2010), Assessment of the quantity of the material transported downstream of Sperchios river, central Greece. Bulletin of the Geological Society of Greece, Proceedings of the $12^{\text {th }}$ International Congress, Patras, Greece.

Van der Knijff J.M., Jones R.J.A. and Montanarella L. (2000). Soil erosion risk assessment in Italy. EUR 19044 EN, Office for Official Publications of the European Communities, Luxembourg, 44pp.

Wischmeier W.H. and Smith D.D. (1978). Predicting Rainfall Erosion Losses, A Guide to Conservation Planning, Agriculture Handbook No 537, U.S. Department of Agriculture, Washington, USA.

Zarris D., Vlastara M. and Panagoulia D. (2011), Sediment delivery assessment for a transboundary Mediterranean catchment: the example of Nestos river catchment, Water Resources Management, doi:10.1007/s11269-0119889-8. 